\title{
THE SYMBOL AND THE ICON - VISIBLE MANIFESTATIONS OF CHRIST IN THE HOLY LITURGY
}

Ciprian Ioan STREZA*

\begin{abstract}
As visible manifestations of the eschatological realm in the liturgical practice of the Church, the symbol and the icon belong to the empirical world, and their characteristic note is given by their correlation with the transcendence. By the agency of the Holy Spirit, the two become environments through which Christ reveals His presence and saving actions in the Church. They both unveil and shroud, at the same time, the novel reality of the Aeon to come, for in this world "we know only in part", in such a manner, so as to make the man crave eschatological perfection. Both the icon and the symbol engage the human spirit in its wholeness, which in turn requires a certain degree of ascesis and spiritual delicacy in order to perceive their message. The liturgical symbol is both an "icon" of the economy of salvation and an "icon" of the world to come. During the Holy Liturgy, everything becomes a window to the eschatological realm, all the painted icons and the liturgical rituals point to the mystical Eucharistic Reality, the warrant of our future wholeness.
\end{abstract}

Keywords: Liturgy, Ascesis, Symbol, Eschaton, Mystagogy

Similar to any spiritual organism, the Christian Liturgy did not morph into being all at once, as if it were an entirely new, unprecedented and spontaneous creation. Its history did not begin at the same time as Christianity arose. Although its mystical core and essence was established by the Saviour during the Mystical Supper, the foremost ideas that make up its stem, nucleus or seed, as well as its formal manifestations are deeply rooted in history, as they carry on a tradition and ritual inspired from the Old

PhD, Professor, "Lucian Blaga" University in Sibiu (Faculty of Orthodox Theology), Romania. 
Testament and draw their sap from the primordial revelation and the beginnings of the sacred history of our salvation ${ }^{1}$.

Everything that happens during this Mystery of God's descent and dwelling within and among people, which is the Holy Liturgy, becomes accessible to men only through faith, via their sacramental-objective and current-subjective ethical and ascetical embedding into the life of the Church, an experience by which they seek to grasp the sacramental mystery.

God's presence in the Holy Liturgy is gradually unveiled, and all the visible acts, along with the entire ecclesial realm, lead the faithful to the discovery and experience of its mystery. The Church employs the symbol and the icon as modes of initiation in the sacramental mystery, as they assist the man in his passage from mere visual perception to spiritual contemplation and mystical experience of the acts pertaining to the iconomy of salvation.

The Byzantine comments on the Liturgy, ascribed to Saint John Chrysostom, bring to light the truth that the Eucharistic celebration, which serves as an icon of the Kingdom to come and as the initiation path into this new eschatological reality, has its fundamental visual elements converging into icons and symbols that not only connect the seen substance to the unseen, but also bring this very eschatological reality into contemporaneity.

Icons inhabit the Church, for what the Gospel reveals through words and the liturgical acts suggest through symbols, the icon proclaims through colours. The Holy Liturgy is where the real meeting and union with Christ takes place through the Holy Eucharist, and all the liturgical acts as well as the entire ecclesial environment are meant to initiate the believer in this unique and mystical sampling of the eternal life.

The icon and the symbol are bridges between two worlds. It is through them that the man can connect with the live reality of God, that surpasses all senses, through them he can foresee the age to come in the fluttering reflections of the faces of this world ${ }^{2}$.

When contemplated in their beauty and apophatism, both the liturgical acts and the icons go beyond being simple and loyal expressions of the

${ }^{1}$ ENE BRANIŞTE, Liturgica Specială (Special Liturgics), Bucureşti, 1980, p.167. For the Judaic cultic frameworks wherein the Christian Anaphora was born, see: LOUIS BOUYER, La première Eucharistie dans la dernière cène, Maison Dieu no. 18 (1949), p.34-47; LouIS Ligier, “De la Cène de Jésus a l'anaphore de l'Eglise", in La Maison Dieu, no.87/1966, p.751.

${ }^{2}$ P. FlorensKy, “L'icône”, in Contacts, no.4/1974, p. 325. 
history of salvation. They mystically introduce the believers to the whole salvation work in its liturgical and sacramental actualization: "The Mystical Supper has not concluded yet. The roar of Pentecost lingers still... Baptised and immersed in the grace of the new creation and then welcomed into the iconographic and liturgical world, we find the Lord and His saints living in the unmediated touch and the zoetic communion." 3

In order to understand the symbol-icon dialectics in the Orthodox rite, the current article will analyse in the following paragraphs the two concepts separately, and then will proceed to emphasize the importance of their correlation as visible proofs of the liturgical mystery, in the most critical interpretations of the Byzantine Liturgy.

\section{Symbol and Symbolization: the possibility to iconize and participate in a different world.}

The ancient Greeks considered the symbol a mark, a sign of recognition or identification that was made up of a coin broken in two, half of which was given to a guest or a merchant for further recognition purposes ${ }^{4}$. In the early Christian times, the fish symbol was used as a sign of recognition amongst Christians.

By its etymology, this term denotes a material sign that evokes in our minds a reality that is different than the one we see. Originating from the verb $\sigma \cup \mu \beta \alpha \dot{\alpha} \lambda \varepsilon \varepsilon \iota$, that means 'to unite' or 'to put together', the symbol is an indicator of what is beyond its substance; it is not a reality in itself, but it exists according to the distinct reality that it points to and actualizes. In its most extensive denotation, the symbol must be understood as 'something' that points to 'something else' on the basis of a similarity that is characteristic to it'

In very general terms, the symbol is catalogued according to its form in the signs category, because it does not exist for itself, but it denotes

${ }^{3}$ ARCHIMANDRITE BASIL, Eisodikon. Elements in the liturgical experience of the mystery of unity in the Orthodox Church, Stavronikita, 1974, p. 123-124.

${ }^{4}$ VGL. M. LURKER (Hg.), Bibliographie zur Symbolik, Ikonographie und Mythologie, BadenBaden 1968; F. HeRmann (Hg.), Symbolik der Religionen, Bd 1, Stuttgart, 1958; M. Eliade, "Methodologische Anmerkungen zur Erforschung der Symbols in den Religionen", in: J. M. KiTAGAwa (Hg.), Grundfragen der Religionswissenschaft, Salzburg, 1959; H. BIEZAIS (Hg), Religious Symbols and their Functions, Uppsala 1979; S. v. BELOW u.a., Symbollexikon, Gütersloh, 1986; H.R. SCHLETTE, "Symbole", in: Encyclopedie de la foi, IV, p.279.

${ }^{5}$ H.R. SCHLETTE, "Symbole", in Encyclopedie de la foi, IV, p.279. 
something, it points to something else. The symbol marries the sensory and spiritual planes. However, since this union cannot be fully realized due to the dissimilarities between the two realities, the symbolization act produces a characteristic tense moment, as it pushes all the spiritual faculties of the man, who is thus challenged by the symbol to transition from the seen to the unseen, from material to spiritual ${ }^{6}$.

The symbol is far from a simple sign, even though both refer to a reality that is beyond them. Unlike the sign, the symbol actually participates in the fortitude of the reality it represents, by actualizing it. The correlation with transcendence is the characteristic note of the Christian symbol. The religious symbol both envelops and unveils a spiritual presence, uncovers the deep, fundamental dimension of reality, for all that we see is nothing else than the image and icon of the divine prototype. In quoting Berdyaev, Fr. Prof. D. Stăniloae states: "Both the symbol and the symbolization presuppose the existence of two separate worlds, of two registers of being... The symbol serves as a bond between two worlds... it proves the existence of another world and the possibility to form a union between this world and the other one. The symbol distinguishes but also ties two worlds."7

Therefore, the symbol represents the discovery of a certain something, of a different world, as it envelops in itself two realities, the visible empirical and the spiritual, invisible one, which it unites not in a logical manner ("this" stands for "that"), nor via a cause-effect link ("this" is "the cause of this"), but altogether in an epiphanic fashion (from é $\pi \iota \varphi \alpha i v \omega$ - "to discover"). Within the symbol, everything discloses the spiritual reality and every aspect of it is needed for this discovery. And yet, not all of the spiritual reality is uncovered, for the symbol stands always for a part, "For we know in part, and we prophesy in part" (I Cor 13, 9). In other words, everything in the symbol uncovers the spiritual reality through a process that is conditioned by the symbol itself being a participant in it; and yet not everything in this spiritual reality has a representation within that symbol. The symbol always exposes only a fragment of the reality it stands for, which it partially unveils, partially covers, and thus it increases the man's nostalgia and longing for the

${ }^{6}$ P. PARousel, "Symbol", in: H. Waldenfels (ed.), Lexikon der Religionen, Freiburg, Basel, Wien, 1987, p.625.

${ }^{7}$ Ibidem, p.434. 
life and the world to come ${ }^{8}$.

The essence of the symbol inheres in the fact that in it the dichotomy between reality and symbolism as unreality is surpassed, for the reality is known above all as the fulfilment of the symbol, and the symbol is seen as the fulfilment of reality. One reality may uncover another reality only in as much as it may participate in the spiritual reality which it points to and which it can embody 9 .

The entire world in its wholeness can be a symbol for the man, as it represents the medium through which he foresees the transcendence. The man has to discover the world's character of symbol. In their teachings about divine reasons that radiate from all worldly things, the Holy Fathers express the world's character of symbol, of a transparent medium that lets the divine transcendence shine through, for at the foundation of all real things and beings lies not the divine Being, but the divine forms, types and paradigms according to which God created the whole world. Behind the "rough coating of the materiality" of this world, the Holy Fathers saw the true and immortal essence of the eternal world. "They were taught by the Logos-Creator that lay hidden within them, by the sight of spiritual contemplation of each visible symbol, and through the Logos they found God."10 Therefore, "the whole perceptible world is mystically imprinted on the whole sensible world in symbolic pictures for those who have eyes to see; conversely the whole sensible world, when examined by a knowledge inclined mind, is embodied in the perceptible world by the very principles which it contains." 11

The substance has thus become the means towards the uncovering of Christ's presence in the Church, for after His Ascension into Heaven, "He who was visible as our Redeemer has now passed into the Sacraments", as Leo the Great states ${ }^{12}$, which also made Saint Ambrose the Great exclaim: "I

${ }^{8}$ Al. SchmemanN, Euharistia-Taina Împărăţiei (The Eucharist - Sacrament of the Kingdom), 1984, Romanian transl. by BORIS RĂDUCANU, Anastasia Publishing House, Bucureşti,1992, p.45.

${ }^{9}$ D. STĂNILOAE, "Simbolul, anticipare şi temei al posibilităţii icoanei (The symbol, anticipation and cornerstone for the possibility of the icon)", în Studii Teologice (Theological Studies) no. $7 / 1957$, p. 431.

${ }^{10}$ Saint MAXIMUS THE CONFESSOR, "Răspunsuri către Talasie 49 (Answers to Thalassios 49)", Filocalie (Philokalia) vol. III, Sibiu, 1948, p. 36.

${ }^{11}$ IDEM, Mystagogia 21, PG 912, 697 A

12 Sermo 74,2; PL 54, 398A. 
find Thee Lord in Thy Mysteries!"13 Within the Mysteries, the substance is not a mere symbol, it is filled with God's grace and serves as a means by which the Christians really participate in the reality that is therein symbolized $^{14}$.

"Instead of Christ's corporeal being, the world now fully enjoys His spiritual presence, ready to be experienced through faith and the Holy Mysteries, a presence which is ever more intense than the former, for it is entirely rooted in the Holy Spirit and the Body of the Lord has now become pneumatic... Therefore, the Mysteries unveil not the kenosis of the Lord, but the divine power of the transfigured body, for it is through them that the divine power is revealed." 15

\section{The icon - charismatic topos and window to the Kingdom of Heaven}

The icon expresses the link between the empirical "seen" reality and the "unseen" spiritual one on another level and in a different manner, because its purpose, as well as the symbol's, is to go beyond the act of unveiling heavenly beauties and raising the human powers of reasoning to the contemplation of God's embodied beauty, and thus convey the sanctifying power of the Holy Spirit. The icon actualizes the reality that it points to and facilitates for the believer a personal encounter with the event or the holy person artistically depicted in it.

Just like in the case of the symbol, the foundation and the possibility of the icon is given by the very act of creation, by the iconic structure and vocation of the man, who was created in the image of God and meant to attain likeness with Him, but most of all, by the Incarnation of the Divine Logos, Who came into the world in order to restore the image of the fallen man. Saint John of Damascus writes "... Now, however, when God is seen clothed in flesh, and conversing with men, (Jn 1,14, 1 Tim 3,16) I make an image of the God Whom I see. I do not worship matter, I worship the God of matter, Who became matter for my sake, and deigned to inhabit matter, Who worked

${ }^{13}$ Apologia Prophetae David, in Odo CASEL, Das christliche Kultmysterium, Regensburg, 1932, p.19.

${ }^{14}$ D. Stăniloae, Teologia Dogmatică Ortodoxă (Orthodox Dogmatic Theology), vol. 3, Bucureşti, 1978, p. 21.

${ }^{15}$ ODOCASEL, "Mysteriengegenwart", in Jahrbuch für Liturgiewissenschaft no.8/1955, p. 154-155. 
out my salvation through matter." 16 The entire iconomy of salvation proves and fulfils the purpose of the incarnation of the Son of God, which is to convert the man and the whole creation into an icon of the eternal Kingdom, to remodel the entire creation and bring it before God. The icon both anticipates the Eschaton and actualizes it; hence, it represents a perpetual miracle in the life of the world ${ }^{17}$.

The holy icons are "windows of eternity" not because they visibly reproduce an invisible reality, but because they are charismatic presences that attract and inspire the man towards interpersonal communication ${ }^{18}$. It is through this means that the person depicted in the icon communicates with those who pray before it, the icon makes it possible that they meet in the realm of faith. Just like the symbol, the icon reveals and at the same time covers a spiritual presence, as the sacred art is as laconic as the Gospel is ${ }^{19}$, for it puts aesthetics to the service of the senses, pointing only to what is essential, meaning to awaken the man's longing for immersion in the knowledge and experience of that very presence.

According to Saint John of Damascus, icons are by their nature on the same register with the human nature of the Incarnate Son of God: "I have watched God's human image and my soul was saved" 20 , yet the distinction between the presence in the icon and the person represented is defined by Saint Theodore the Studite: "The prototype is in the icon not according to the modality of substance, for then it would be fit to call the icon a prototype and vice versa, the prototype an icon, but according to the resemblance of the hypostasis." 21 The icon mediates a relational presence, not a confusion or

${ }^{16}$ Saint John of Damascus, Cele trei tratate contra iconoclaştilor (On Holy Images) I, 16, Romanian transl. by D. Fecioru, Bucureşti, 1937, p. 17:

${ }^{17}$ IOAN BIZĂU, Incursiuni în teologia şi arta icoanei (Journeys into the theology and art of the icon), in: LEONID USPENSKY / BORIS BOBRINSKOY / STEPHAN BIGAM / IOAN BIZĂU, Ce este icoana? (What is the icon?), Alba Iulia, 2005, p.87.

${ }^{18}$ Michael KunZleR, Die Liturgie der Kirche, in Lehrbücher zur katholischen Theologie, X, Paderborn, 1995, p. 224.

${ }^{19}$ LEONID USPENSKY, Icoana, vedere a lumii duhovnicessti (The icon, a window to the spiritual world), in: LEONID USPENSKY et alii, Ce este icoana?, p.26.

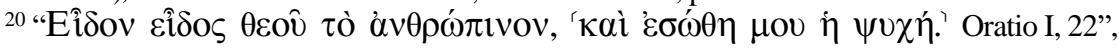
in: B. KotTER, Die Schriften des Johannes von Damaskos, in Patristische Texte und Studien, 17, Berlin, 1975, p.111.

${ }^{21}$ Saint TheOdore tHe STUdite, "Antiereticul III (Anti-heretic III)", Romanian transl. by I. IČ̃ jr., in: Saint Theodore the Studite, Iisus Hristos, Prototip al icoanei Sale. Tratate contra 
mixture of realities, and that gives it a miraculous character ${ }^{22}$.

Through the faith and piety filled gaze, the icon facilitates the mystical meeting with the persons represented, just as the symbol mediates the actual presence of the spiritual reality symbolized. In both cases, the bridge between the two realities is possible only through faith. In this respect, it is very important to draw a side-by-side comparison between the Holy Gospels and the Liturgy, just as it is mentioned in the patristic literature ${ }^{23}$, which highlights the fact that Christ's mystical presence in the Church after His Resurrection and Ascension is made manifest in the Mysteries, the Holy Scriptures, the icons and through the symbolism of the cult. The Liturgy actualizes what the Icon uncovers through the sense of sight and the Gospel unveils through the sense of hearing. The Fathers of the VIIth Ecumenical Council issued a clear explanation of this reality:

"the iconographic representation is inseparable from the scriptural history and vice versa: the scriptural account is inseparable from the iconographic representation. Both are good and worthy of honour, for they mutually explain one another and undoubtedly bear witness one for the other.... For what the word tells to the ear, the painting silently tells to the eye by representation... By these two means that make each other whole... we receive the knowledge of the same thing." 24

The icons and the Gospel both belong to the Liturgy. In any icon of Christ, as well as in the Holy Scripture one may truly "see" the iconomy of the Lord Incarnate. However, during the Liturgy, the salvation activity is not only represented, but also actualized. Everything in the Church services - the word, the chant, the architecture and the cult - is in perfect harmony through the work of the Holy Spirit. Christ is confessed and actualized in various ways, so that the man might participate in the spiritual reality with his whole

iconomahilor (Jesus Christ, prototype of His icon. Treatises against iconoclasts), Alba Iulia, 1994, p. 153.

22 IOAN BIZĂU, Incursiuni în teologia şi arta icoanei... (Journeys into the theology and art of the icon), p. 93.

23 D. StănilOAe, "Simbolul, anticipare şi temei al posibilităţii icoanei (The symbol, anticipation and cornerstone for the possibility of the icon)", in Studii Teologice (Theological Studies), no.7/1957.

${ }^{24}$ Definiţia dogmatică a Sinodului VII Ecumenic de la Niceea (The dogmatic definition of the VIIth Ecumenical Council in Nicene), in H. DENZINGER, Enchiridion Symbolorum, Freiburg, 1955, p.308. 
being.

"In order to morph into a harmonious ensemble, each component part of a church must be, above all, subject to the general intention and thus it must renounce any ambition of having a personal input, or of having an intrinsic value. The icon, the chants cease to be mere artistic expressions representing separate, independent paths, and they become different forms of expression for the same general idea of 'church', i.e. an universe transubstantiated, the foresight of the peace to come. This is the only way that each art that is part of a harmonious whole may reach perfection. ${ }^{25}$

Thus, the art of the Church in its essence is a liturgical art. Not only does it serve as a framework for the entire worship, but it also completes it and morphs onto it entirely. Sacred art and Liturgy form a whole, both by their content and by the symbols they employ. The image originates in the text, to which it lends its iconographic themes and the way to express them. At the same time, the entire liturgical ritual has always been perceived as an icon of the Saviour's life, which has always held soteriologic efficiency ${ }^{26}$.

Similarly, the sacred image does not represent only a historic event or a certain human being, but it shows the eternal image of the same, it unveils its dogmatic meaning and its place in the train of redemptive events of the divine iconomy; it already radiates, by and through itself, the wholeness of this iconomy that the Holy Liturgy brings into the present.

\section{The symbol - icon connection in the history of Liturgical exegesis}

The most important liturgical commentaries of the Orthodox Church point to the role of the symbol and the icon, which both give an account and actualize the same presence of Christ in the Liturgy ${ }^{27}$. The main parts of the Liturgy have gone through a gradual evolution. It is a "cosa cipollata", as Robert Taft calls it ${ }^{28}$. During the first centuries, the Liturgy was improvised

${ }^{25}$ LEONID USPENSKY, "Icoana, vedere a lumii duhovniceşti (The icon, a window to the spiritual world)", in: LEONID USPENSKY et alii, Ce este icoana? p. 20.

26 See: Nicholas CABAsilas, Tâlcuirea Sfintei Liturghii (A Commentary on the Divine Liturgy), P.G.150, 368-492. critical ed. by R. Bornert, J. Gouillard, P. Perichon. transl. and notes S. Salaville, Paris 1967, SC 4bis, Romanian transl. by E. Branişte, Bucureşti, 1946.

${ }^{27}$ See the highly documented papers regarding: H. J. Schulz, Die byzantinische Liturgie. Vom Werden ihrer Symbolgestalt, Freiburg im Breisgau, 1964; RENE BORNERT, Les commentaires byzantins de la divine Liturgie du VII au XV siecle, Paris 1966.

${ }^{28}$ ROBERT TAFT, "Reconstructing the History of the Byzantine Communion Ritual: Principles, 
according to a certain prayer template which was rooted in the Apostolic practice. From its early simple form, new rites have slowly developed; the more complicated it became, the greater the need to explain it.

The evolution of theological thinking has influenced the history of the Liturgy in its entirety and the exegesis of each liturgical act. The newly introduced rituals in time were received at first as visible expressions of the liturgical mystery, without any typological or eschatological symbolistics attached. At a later evolutionary stage, these newly acquired liturgical acts have been endowed with their own set of symbols, the purpose being to re-present visibly what the Eucharistic Liturgy was accomplishing sacramentally.

The documents dating back to the second half of the first century and the beginning of the second, the Christian Eucharist, which had inherited some elements of the Judaic blessing (berakah), is depicted as a "source of gnosis" along with the Holy Scripture, as they were realities in need of interpretation, that also required some initiation into their mystery. Historically, the initiation in the mystery of the Holy Liturgy has known two modes of expression, namely the one characteristic to the school of Alexandria and that typical of the school in Antioch. The first mostly saw the Church, the Mysteries and the Holy Liturgy as images of heavenly realities, the Alexandrian mystagogy [introduction to the Mystery] was characterized by anagogy and represented the liturgical celebration as a sampling of the Heavenly Kingdom, while the Antiochian depicted their historic and typologic dimension, with a special emphasis on the relation between the Holy Liturgy and the events in the earthly life of Jesus Christ, wherein the liturgical acts represent the entire life of the Saviour ${ }^{29}$.

The Antiochian interpretation of the Holy Liturgy is the one that received the widest reception, and not because of its typologic symbolism that was easily accessible to the vast majority of believers, but rather due to the influence exerted by the Antiochian cult on Constantinople, which also meant that wherever the Byzantine rite expanded, the Antiochian mystagogy closely followed.

Therefore, to Saint John Chrysostom, the Holy Liturgy is a Mystery, a mystical event, and its entire celebration is both an anamnesis of the iconomy of salvation, and an unveiling of heavenly realities:

Methods, Results", in Ecclesia Orans, no. 11/1994, p. 355.

${ }^{29}$ R. BORNERT, Les commentaires..., p. 49. 
"Believe, therefore, that even now it is that supper, at which He Himself sat down. For this is in no respect different from that. For neither does man make this and Himself the other; but both this and that is His own work. When therefore you see the priest delivering it to you, do not consider that it is the priest that does so, but that it is Christ's hand that is stretched out." ${ }^{30}$

In the spirit of the Antiochian tradition, the Eucharist is for the same holy father a re-presentation of the iconomy of salvation as well as its perpetual reactualization: "If we draw near, our hearts brimming with faith, we will surely see the Lord lying in the manger. That is why the Prothesis symbolizes the manger. And here we will see the Lord sitting not wrapped in swaddling clothes like in the old times, but completely engulfed by the Holy Spirit." ${ }^{11}$ It is obvious that to Saint John Chrysostom, the symbol has a double function: the liturgical ritual uncovers the historic reality of Christ's life, as all the acts of the Liturgy are images of the Saviour's redeeming work, and the eschatological reality of eternal life, via Christ's actual presence in the Eucharist.

Going further than Saint John Chrysostom, Theodore of Mopsuestia gives a personal interpretation in his catechetical homilies ${ }^{32}$ by directing his attention towards the seen form of the Liturgy. Christ is the One present in the Eucharist, yet He is aided in His work by the priests one can see, whose acts mediate and actualize Christ's work. In this respect, Theodore states: "Those who have been chosen as the priests of the New Testament are believed to perform sacramentally, by the descent of the Holy Spirit, these things which we believe that Christ our Lord performed and will perform in reality." ${ }^{33}$ As the priest represents the icon of Christ, so must be the liturgical acts of the historical iconomy of salvation, especially those pointing to the Resurrection. Even more thoroughly than Saint John Chrysostom, Theodore of Mopsuestia highlights the fact that the Liturgy is an anamnesis of the historical work of salvation through Resurrection and that the realization of this anamnesis is visible through liturgical gestures, which are closely shown

30 “In Mt. Hom. 50", 3, PG 58, 507.

31 "Hom de beato Philogono 6, PG 48, 753.

32 R. Tonneau / R. DevreEsse, (Hg.), "Les homélies catéchétiques de Théodore de Mopsueste", in Studi e Testi, 145, Città del Vaticano, 1949.

33 “Hom. cat. 15, 19”, in R. Tonneau/ R. Devreesse, Les homélies catéchétiques..., p.495. 
and interpreted as images, typologies and symbols, all mediators of reality ${ }^{34}$.

Theodore of Mopsuestia's sermons are the first in the history of liturgical exegesis to attach an exact corresponding event from the Saviour's life to each liturgical act. Thus, the most important parts of the Liturgy (the bringing of gifts, the Anaphora and the words of institution, the Epiklesis and the Communion) are synchronized with stages in Christ's life, from His Birth, right to His Resurrection and Ascension.

It is important to note that both Theodore and Saint John Chrysostom associate the symbolism of the salvation history in the Liturgy with the icon, as both make manifest the reality of the Incarnation via the seen matter. Theodore of Mopsuestia sees in symbol and in icon a connection between the seen and unseen world, between heaven and earth, between the present moment and the Eschaton. The real and eschatological presence of Christ in the Liturgy transfigures everything, hence all the liturgical acts and garments are highly significant and mean to draw attention on the presence of eternity in time, of uncreated within the created, of God among people.

In Saint John Chrysostom and Theodore of Mopsuestia's time, there was a close theological and liturgical exchange between Constantinople and Antioch, which pushed the symbolic-typologic centred interpretations of the Liturgy to the entire Orthodox world. From the Vth-VIth centuries on, the role of Alexandria would expand, and that would lead to some important changes both in the ritual and in the exegesis of the Liturgy:

"In the Neo-Chalcedonianism of the VIth century, writes Hans Joachim Schulz, a growing number of Orthodox Christians have adopted an Alexandrian mindset and started to apply Cyril's terminology in the Chalcedonian theological system, and thus they sacrificed Antiochian Theodoret and Theodore, who had previously been considered Orthodox. This transformation and confrontation is reflected even in the Byzantine Liturgy. The introduction and use of the Trisagion in the Byzantine Liturgy shows the fight against Monophysitism, with Saint Dionysus the Areopagite's critical interpretation of the Holy Liturgy being the sign of a spiritual position that strived to unite the two fronts, and with the new liturgical texts of the $7^{\text {th }}$ century - mainly the One is Holy and the Cherubic hymns - denoting a return of the Byzantine theology onto an Orthodox-

${ }^{34}$ H. J. ScHULZ, Die byzantinische Liturgie...p. 40. 
Alexandrian path." ${ }^{\prime 35}$

This process can also be inferred from the liturgical commentaries of that time. For Dionysus the Areopagite ${ }^{36}$ all the acts in the Liturgy bear a strict spiritual meaning and are explained as symbols of celestial reality, whose divine brightness is thus transmitted to the faithful people via the first stage of the angelic world and the priests anointed to perform this service. The communication of this awareness, "that takes place in a purely spiritual manner in the world of angels, is reiterated in the Church half-visibly, halfinvisibly, via symbols, mysteries and images, which symultaneously iconize and envelop the realities of the spiritual world." 37

For Saint Dionysus the Areopagite, the icon and the symbol have an anagogic function, since the importance of a ritual is always the product of its connection to the "higher" eschatological reality, and not to the immediate historical one.

The construction of Hagia Sophia is a materialization of this celestialeschatological perspective in the exegesis of the Liturgy. For the first time in the history of the Church and the Liturgy, a liturgical space was created in the grand Church of God's Wisdom from Constantinople, a space that perfectly expressed the spiritual strength of the age, and whose architecture allowed for the Liturgy to unfold mystically as a celestial reality ${ }^{38}$. In Hagia Sophia, the Liturgy and its exegesis are harmonized with theological thinking and art. The icon and the liturgical symbol are entwined in a harmonious and unique way. Everything bears the mark of God, everything points to His presence and makes it manifest.

The perfect harmony of Hagia Sophia Cathedral in emperor Justinian's time influenced the development of the Liturgy. Spacious and lavish, the interior of the church imitates the vastness of the world, its amply arched ceiling floating over the windows wreath like a semblance of the sky. It has been thought of as a visible icon and materialization of the cosmic Liturgy, wherein the created and uncreated, the seen and unseen, the sensible

${ }^{35}$ H. J. SCHULZ, Die byzantinische Liturgie, p. 46.

${ }^{36}$ M. DE Gandillac, G. HeIL, (Hg.), "La Hiérarchie céléste”, in Sources chrétiennes 58, Paris, 1958.

37 Vgl. E. v. IvanKA, "Dionysius Areopagita. Von den Namen zum Unnennbaren”, in Sigilium

7, Einsiedeln, p.13; R. Roques, L'Univers dionysien. Structure hierarchique du monde selon Pseudo-Denys, Paris, 1954, p. 171-174.

${ }^{38}$ H. J. Schulz, Die byzantinische Liturgie, p.62. 
and perceptible come together ${ }^{39}$. Everything in the nave of Hagia Sophia stands under the majesty of the impressive dome, which shows God the Pantocrator in His utmost elevation "looking at us and pulling us into His arms that seem to be just awaiting our filial embrace." "Bo "By its curves, the dome translates the downward movement of divine love, and by its spheric shape, it reunites all people in a liturgical synaxis, in the Body of Christ. Under the dome, we feel sheltered from the pascaline anguish of infinite spaces." 41

This liturgical space, as well as the Liturgy celebrated in it during the Justinian age, have given rise to an interpretation of the Eucharistic Synaxis such as Saint Maximus the Confessor's Mystagogy provides ${ }^{42}$. As far as symbolic interpretation, Saint Maximus is worlds apart from Dionysus the Areopagite, whom he often refers to and whom he also distances himself from with his description of the relation between the ecclesial space and the universe, the man, the Holy Scripture. Therefore, in the first part of his Mystagogy, he characterizes this relation by words like "image", "allegory", "likeness", without striving - like Dionysus did - to follow a gradually increasing symbolization, in a sacramental or quasi-sacramental manner, starting from the ecclesial reality and aiming to reach the celestial one. His intention is better identified in his frequent affirmation of the bipolarity "heavenly-earthly" concerning realities such as Church, universe, man, which mutually symbolize one another (only) in this sense $e^{43}$.

Although it employs the same method of the speculative-symbolic

39 O. WulfF, "Das Raumerlebnis des Naos im Spiegel der Ekfrasis", in: Byzantinische Zeitschrift, no. 30/1929, p. $531 \mathrm{ff}$.

40 Dumitru Stăniloae, Spiritualitate şi comuniune în liturghia ortodoxă (Spirituality and Communion in the Orthodox Liturgy), Craiova, 1986, p. 39

${ }^{41}$ Paul Evdokimov, L'art de l'icône, Paris, p. 126.

${ }^{42}$ P.G. 91, 657-718; Fr. transl. in M. Lot-Borodine in Irenikon no. 13-15/1936-1938; Romanian transl. by D. Stăniloae in Revista Teologică (Theological Review), Sibiu, no. 3-4 and 78/1944; GERMAN transl. by Hans Urs von Balthasar, Kosmische Liturgie, Einsiedeln, 1961, p.366-407. French transl. in: Marie-Lucie Charpin-Ploix, Maxime le Confesseur, La Mystagogie, Introduction, traduction, notes glossaires et index de Marie-Lucie CharpinPloix, Paris, 2005; C. Boudignon, La Mystagogie, ou trate sur le symboles de la Liturgie de Maxime le Confersseur, Edition, traduction, commentaire, Paris, 2000; C. Sotiropoulos, La Mystagogie de Saint Maxime le Confesseur, Introduction, texte critique, traduction francaise et grecque par C. Sotiropoulos, Athens, 2001; R. Cantarella, (ed.), S. Massimo Confessore. La mistagogia ed altri scritti, Testi Cristiani, Florence, 1931, p. 122-214.

${ }^{43}$ H. J. SCHUlZ, Die byzantinische Liturgie, p.83. 
Alexandrian inspired “theory", Saint Maximus's Mystagogy is founded on a rationale which acts as its structural principle and which is completely different from Dionysus's. While the entire speculative edifice of the hierarchic system of Saint Dionysus the Areopagite is structured on the fundamental metaphysical motif of the universal, cosmic and hierarchic sacred meditation, the whole Maximian theological expression is firmly centred on the Christological motif, with the Incarnation being the centre and the purpose of all creation. In truth, Saint Maximus's entire work is nothing else than a gigantic commentary on the speculative-dogmatic and mysticalascetic implications of the Chalcedon formula, elevated at the rank of world formula.

Saint Maximus sees in the Church a Christological structure, and in the hypostatic union, the axis of the world. The manner in which the human and the divine natures are united in the Person of Christ represents Axis Mundi, the sense and possibility of iconographic symbolization and representations in the cult ${ }^{44}$.

During iconoclasm, the fight for the Holy Icons generated a series of theological tensions and dogmatic controversies that influenced the entire Byzantine rite. "The New Church" consecrated by Saint Photios, also known in art history as "Nea", is representative of the way churches were built in times of peace. This church can be seen as a direct expression of the teaching about icons and as a first example of how the decoration system functioned during the Middle Byzantine period, a system that characterized the shape of

44 The Mystagogy of Saint Maximus the Confessor has been interpreted in many studies. Among those, we mention the most important: Ene Branişte, "Biserică şi Liturghie în opera 'Mystagogia' Sfântul Maxim Mărturisitorul (Church and Liturgy in the "Mystagogy" by Saint Maximus the Confessor), in Ortodoxia (Orthodoxy), no.1/1981, p. 13-23; V. M. Zhivov, “ 'The Mystagogia' of Maximus the Confessor and the developement of the byzantine theory of the image", in St. Vladimir's Theological Quarterly, no 4/1987, p. 349-376; Dumitru Stăniloae, "Cosmosul şi sufletul, chipuri ale Bisericii (The cosmos and the soul, images of the Church)”, in Rev.Teologică, Sibiu, no.3-4/1944, p. 166 ff.; H. J. Schultz, "Die byzantinische Liturgie. Von Werden ihrer Symbolgestalt", in Sophia, Quellen östlicher Theologie 5) Freiburg im Breisgau, 1964; H. Dalmais, "Place de la Mystagogie de Saint Maxime le Confesseur dans la theologie liturgique byzantine", in Studia Patristica, 1962, p. 277-283; Rene Bornert, Les commentaires byzantins de la divine Liturgie du VII au XV siecle, Paris 1966, p. 83-124; A. Riou, Le monde et l'eglise, selon Maxime le Confesseur, Paris 1973; Marie-Lucie Charpin-Ploix, Union et difference. Une lecture de la Mystagogie de Maxime le Confesseur, Paris, 2000; Dom Julian Stead, The Church, the Liturgy and the Soul of Man. The Mystagogia of St. Maximus the Confessor, Still River, Massachusetts, 1982. 
churches from the XIth-XIIth centuries and defined in a broader sense the whole Byzantine iconography of later years. The shaping powers of the epoch were stirred by the same perseverance when they moulded the iconography according to the evolution and authentication of theological expression, just as when they influenced the evolution of the Liturgy, as well as the reception of its symbolism. The iconic and eschatological character of the Liturgy is highlighted and inferred from the analysis of the new liturgical acts inserted in the preparation of the Holy Gifts and in the act of laying them on the Holy Table.

Highly important is the fact that the development and exegesis of the Liturgy during this period, and the relation between image and symbol within its interpretation, are detailed in the teachings of the great iconodules of that age.

Saint Theodore the Studite identifies in the Holy Liturgy a cycle of images and symbols that present and actualize the life of the Saviour:

"Think you not, he writes, that the Holy Myron must be understood as typos of Christ, the Holy Table as His life-giving tomb, the Eileton as His burial cloth, the Spear as that with which His side was pierced, the Sponge as that which He was offered to drink vinegar from? - Take these all away and see if there is anything left by which the divine mysteries might be actualized!" 45

The entire liturgical development of the age and its connection to the church teachings about icons is reflected in the commentary on the divine Liturgy by Saint Germanus, Patriarch of Constantinople $(+733)^{46}$, who was forced out of his See at the beginning of iconoclasm (730), following his open intervention in defence of icons. In his commentary on the Liturgy, he also employed the historical-typological symbolism, as well as liturgical forms and symbols, due to their external resemblance to celestial realities and to the salvation history which they pointed to.

Saint Germanus goes even further than Saints Maximus and Dionysus in his depiction of the symbolism of the Saviour's life reflected in the liturgical acts, and attempts even harder than Theodore of Mopsuestia to establish analogies between liturgical acts and stages in the iconomy of salvation, yet without having a unique exegetic principle to rely on

${ }^{45} P G$ 99, 489B.

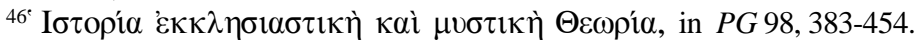


constantly, as the Antiochian theologian $\operatorname{did}^{47}$.

In the XIth century, Theodore of Andida managed to organize the various motifs of exegesis in Patriarch Germanus of Constantinople's commentary, thus somehow succeeding in synchronizing the entire Liturgy, from Prothesis to Communion, with the life of Jesus. This arrangement of liturgical acts and the determination of their symbolism took place at the same time with the establishment of the entire iconographic program for painting the churches in such a way, so that the symbolism of rituals might be accompanied by its visible objectivations in mural paintings and icons.

During the time of Theodore of Andida, the Proskomide is assigned the symbolism of the Saviour's death and that of His birth, as it was necessary to iconize symbolically in the Liturgy a complete chronological account of the life of Jesus Christ. What Theodore of Mopsuestia had once started, Theodore of Andida took further, for he concludes his commentary on the Liturgy by stating that each stage in the Saviour's life, from Incarnation to His Ascension, must be represented in the Eucharistic celebration.

Theodore of Andida did not want to assign in his commentary ${ }^{48}$ a differentiated theological value to each liturgical act or expression, according to their agedness and sacramental effect, but rather he perceived the whole Liturgy as an Icon, as a cycle of images from Christ's life. To him, the visible resemblance of a liturgical act to a certain event of Christ's life banished any impossibility to fully re-present it. Since the Fathers from the Synod in Trullo had already seen in each icon of Christ an anamnesis of the entire salvation work, the more these conclusions had to be applied to the Liturgy, for the Eucharistic celebration is not only an icon or a collection of icons of the Saviour's life that can be found visibly painted in the church, but they also contain the very reality of Christ's Own presence ${ }^{49}$.

"That is why, Theodore of Andida reasons, every believer must know that the entire celebration of the divine Liturgy unveils, in a symbolic manner, through its mysteries, the entire iconomy of the redeeming incarnation of our true God and Saviour Jesus Christ"50.

${ }^{47}$ H. J. SCHULZ, Die byzantinische Liturgie, p.130.

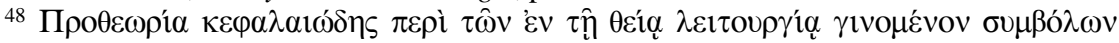

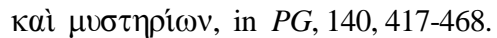

${ }^{49}$ H. J. SCHULZ, Die byzantinische Liturgie, p. 151.

${ }^{50} \mathrm{PG} 140,421 \mathrm{AB}$. 
In his Commentary on the Divine Liturgy ${ }^{51}$, Saint Nicholas Cabasilas takes a special stance towards all the Byzantine commentaries on the Liturgy. His is a work of extreme spiritual importance, for in it the liturgical symbolism not only provides an opportunity to "iconize" the whole life of the Saviour through ritual, but mostly the fulfilment and realization of His sacramental presence.

In his commentary, Nicholas Cabasilas attempts to make a synthesis of the main themes and motifs from the most important liturgical exegeses. The symbolism in the life of Jesus, as it is inferred from the main parts of the Liturgy, has been preserved starting with Theodore of Mopsuestia. Nicholas Cabasilas uses the same order of the events in the Saviour's life as iconized in the Liturgy, which connects him to Theodore of Mopsuestia and Theodore of Andida, to whom it was enough to present His life from the beginning of His passions and to His post-Resurrection epiphanies. Conversely, Saints Maximus and Germanus of Constantinople applied the symbolism of Christ's life only on certain parts of the Liturgy, whereas Symeon took less into consideration the temporal alignment of the iconized events ${ }^{52}$.

Cabasilas' liturgical symbolism is rather a type of foresight than an iconization. With it, Nicholas Cabasilas returns to an ancient understanding of the symbol, found at Saints Maximus and Dionysus the Areopagite. This is shown mostly in the interpretation of the Entrance, whose symbolic character does not lie mainly in an external imitation of Christ's appearance, but rather resides in its resemblance to an equally important significant moment that marks the presentation of the Word - the Liturgy of the Word and the beginning of the Saviour's public mission and of His suffering ${ }^{53}$.

In this way, Nicholas managed to synchronize the unfolding of the Liturgy with the historical stages of the salvation work, without renouncing

$51^{\text {'E } E \rho \mu \eta v \varepsilon i ́ \alpha ~} \tau \hat{\eta} \varsigma$ $\theta \varepsilon \hat{\imath} \alpha \varsigma \lambda \varepsilon \imath \tau o v \rho \gamma^{\prime} \alpha \varsigma^{\prime}, P G$ 1955, p. 368-492. See the critical edition of the text, as well as its French translation: Nicolas CABASILAS, "Explication de la divine Liturgie", Introduction et traduction de S. Salaville, in Sources chrétiennes 4bis, Paris, 1967; English translation: Nicholas CABASILAS, A Commentary on the Divine Liturgy, translated by J.M. Hussey and P.A. Mc. Nulty, with introduction by R.M. French, London, 1960. The Romanian translation can be found in: Nicolae CABASILA, Tâlcuirea dumnezeieştii Liturghii (A Commentary on the Divine Liturgy), Bucureşti, 1946, 1989; See also: Ene BRANișTE, Explicarea Sfintei Liturghii după Nicolae Cabasila (The Holy Liturgy in Nicholas Cabasilas's view), Doctoral thesis, Bucureşti, 1943.

${ }^{52}$ H. J. ScHULZ, Die byzantinische Liturgie, p.204.

${ }^{53}$ H. J. Schulz, Die byzantinische Liturgie, p.210. 
the formal structure of the Liturgical celebrations.

\section{Final conclusions:}

1. Saint John Chrysostom's Divine Liturgy is intrinsically a given which remained unchanged in time, but it is also subject to the process of becoming, for its expression means have gone through perpetual evolvement.

2. In the cult, the icon and the symbol are two forms of expression correlative to the same mystery of Christ. Both belong to one another, none of them follows its own path in the Liturgy, both become revealers of Christ in the Holy Spirit, points where God meets man. Both testify to Christ's work of salvation and to His pneumatic presence in the Church through the Holy Mysteries.

3. The rituals are "icons" of our Lord's iconomy, but they are also "icons" of the world to come, of the Kingdom of God. Similar to the icons, the main function of the liturgical symbol is not to create "emotions", or re-enact past historical events, but to bear witness for the coming and the presence of God in each sacramental act. Both icon and symbol are loci where two subjects meet in faith, they are windows to the eternal Kingdom, and they mediate the here-and-now pre-sampling of the happiness to come.

\section{References}

1. *** Encyclopedie de la foi, IV, p.279.

2. ARCHIMANDRITE BASIL, Eisodikon. Elements in the liturgical experience of the mystery of unity in the Orthodox Church, Stavronikita, 1974.

3. BIEZAIS, H., Religious Symbols and their Functions, Uppsala 1979;

4. BORNERT, Rene Les commentaires byzantins de la divine Liturgie du VII au XV siecle, Paris 1966.

5. BOUYER, Louis, La première Eucharistie dans la dernière cène, in La Maison Dieu, no. 18/1949.

6. BRANIŞTE, Ene, "Biserică şi Liturghie în opera 'Mystagogia' Sfầntul Maxim Mărturisitorul (Church and Liturgy in the "Mystagogy" by Saint Maximus the Confessor), in Ortodoxia (Orthodoxy), no.1/1981.

7. BRANIŞTE, Ene, Liturgica Specială (Special Liturgics), Bucureşti, 1980.

8. CASEL, Odo, "Mysteriengegenwart", in Jahrbuch für Liturgiewissenschaft no.8/1955.

9. CASEL, Odo, Das christliche Kultmysterium, Regensburg, 1932.

10. CharPIN-PloIX, Marie-Lucie, Union et difference. Une lecture de la 
Mystagogie de Maxime le Confesseur, Paris, 2000

11. Dalmais, H. "Place de la Mystagogie de Saint Maxime le Confesseur dans la theologie liturgique byzantine", in Studia Patristica, 1962.

12. GANDILlaC, M. / HeIL, H., "La Hiérarchie céléste", in Sources chrétiennes 58, Paris, 1958.

13. DENZINGER, H., Enchiridion Symbolorum, Freiburg, 1955, p.308.

14. EvdOKIMOV, Paul, L'art de l'icône, Paris, p. 126.

15. IVANKA, E. V., "Dionysius Areopagita. Von den Namen zum Unnennbaren", in Sigilium 7, Einsiedeln.

16. Kitagawa, J. M., Grundfragen der Religionswissenschaft, Salzburg, 1959;

17. KotTer, B., Die Schriften des Johannes von Damaskos, in Patristische Texte und Studien, 17, Berlin, 1975.

18. KunZleR, MichAEL, "Die Liturgie der Kirche", in Lehrbücher zur katholischen Theologie, X, Paderborn, 1995.

19. LURKER, VGL. M., Bibliographie zur Symbolik, Ikonographie und Mythologie, Baden-Baden 1968;

20. NichOlas CABASILAS, Tâlcuirea Sfintei Liturghii (A Commentary on the Divine Liturgy), P.G.150, 368-492.

21. Tonneau R. / R. DevreEsse, (Hg.), "Les homélies catéchétiques de Théodore de Mopsueste", in Studi e Testi, 145, Città del Vaticano, 1949.

22. RIOU, A., Le monde et l'eglise, selon Maxime le Confesseur, Paris 1973.

23. RoQUES, R., L'Univers dionysien. Structure hierarchique du monde selon Pseudo-Denys, Paris, 1954, p. 171-174.

24. Saint JOHN OF DAMASCUS, Cele trei tratate contra iconoclaştilor (On Holy Images) I, 16, Romanian transl. by D. Fecioru, Bucureşti, 1937.

25. Saint MAXIMUS THE CONFESSOR, "Răspunsuri către Talasie 49 (Answers to Thalassios 49)", Filocalie (Philokalia) vol. III, Sibiu, 1948.

26. SaINT TheOdORE THE StUdite, Iisus Hristos, Prototip al icoanei Sale. Tratate contra iconomahilor (Jesus Christ, prototype of His icon. Treatises against iconoclasts), Alba Iulia, 1994.

27. SCHMEMANN, Alexander, Euharistia-Taina Împărăţiei (The Eucharist Sacrament of the Kingdom), Romanian transl. by BORIS RĂDUCANU, Anastasia Publishing House, Bucureşti,1992.

28. Schultz, H. J., "Die byzantinische Liturgie. Von Werden ihrer Symbolgestalt", in Sophia, Quellen östlicher Theologie 5) Freiburg im Breisgau, 1964.

29. STĂNILOAE, Dumitru, "Cosmosul şi sufletul, chipuri ale Bisericii (The cosmos and the soul, images of the Church)", in Rev.Teologică (Theological Review), Sibiu, no.3-4/1944.

30. STĂNILOAE, Dumitru, "Simbolul, anticipare şi temei al posibilităţii icoanei 
(The symbol, anticipation and cornerstone for the possibility of the icon)", în Studii Teologice (Theological Studies), no. 7/1957.

31. Stăniloae, Dumitru, Spiritualitate şi comuniune în liturghia ortodoxă (Spirituality and Communion in the Orthodox Liturgy), Craiova, 1986.

32. StăniloAe, Dumitru, Teologia Dogmatică Ortodoxă (Orthodox Dogmatic Theology), vol. 3, Bucureşti, 1978.

33. STEAD, Julian, The Church, the Liturgy and the Soul of Man. The Mystagogia of St. Maximus the Confessor, Still River, Massachusetts, 1982.

34. TAFT, RoberT, "Reconstructing the History of the Byzantine Communion Ritual: Principles, Methods, Results", in Ecclesia Orans, no. 11/1994.

35. USPENSKY, Leonid / BOBRINSKOY, Boris / BIGAM, STEPHAN / BIZĂU, IOAN, Ce este icoana? (What is the icon?), Alba Iulia, 2005.

36. WulfF, O., "Das Raumerlebnis des Naos im Spiegel der Ekfrasis", in: Byzantinische Zeitschrift, no. 30/1929, p. $531 \mathrm{ff}$.

37. ZHIVOV, Viktor Markovich, "The Mystagogia of Maximus the Confessor and the developement of the byzantine theory of the image", in St. Vladimir's Theological Quarterly, no 4/1987.

38. ·FLORENSKY, Pavel, "L'icône", in Contacts, no. 4/1974. 